\title{
Jurisdição e contencioso administrativo
}

Este trabalho focalizará apenas o artigo 205 da Constituição Federal. Aquele que, ao sentir de muitos ilustres doutrinadores, cria verdadeiro contencioso administrativo. Ou seja: aquele capaz de produzir decisőes definitivas, sem revisão pelo Judiciário. Produtor de decisões em função de litígios que não podem ser apreciados pelo Judiciário. Controvérsias às quais esse poder não teria acesso. Que seriam solucionadas, por última voz, pela autoridade administrativa.

Seu conteúdo:

"Art. 205 - As questøes entre a União, os Estados, o Distrito Federal, os Municípios e respectivas autarquias, empresas públicas e sociedades de economia mista, ou entre umas e outras, serão decididas pela autoridade administrativa, na forma da lei, ressalvado ao acionista procedimento anulatório dessa decisão" lartigo acrescentado pela Emenda Constitucional n. 7, de 13 de abril de 1977 .

A jurisdição:

A exegese correta desse preceito exige palavras sobre a jurisdição.

Dizer o direito aplicável a uma controvérsia é competência que o constituinte entrega, primordialmente, ao Poder Judiciário.

Todos podem, à vista de caso concreto, aplicar dada norma a dado fato. O Poder Executivo o faz com freqüência (por meio de Tribunais próprios): 0 particular, igualmente (basta que seja chamado pelas partes interessadas para dizer quem o direito socorre).
O juris discere decorre da interpretação do sistema normativo. Interpretada a norma, aplica-se ela ao caso concreto.

Vê-se, portanto, que qualquer um pode, em tese, fazê-lo. Porém, insistimos antes, essa função é entregue ao Judiciário.

Assim, para qualificá-la - tal como exercitada por esse Poder - é preciso salientar que, sobre aplicar o direito ao caso concreto, essa dicção tem a marca da definitividade. Ademais, o constituinte coloca a serviço do judiciário toda a força das instituiç̃̃es estatais.

Assim, se o devedor recusa cumprir decisão determinadora de pagamento e resiste ao desapossamento de bens que garantam o ressarcimento do credor, o juiz é autorizado a requisitar força policial (do Executivo) com vistas a obter o cumprimento da decisão.

Se o Governador do Estado descumpre ordem ou decisão Judiciária, a hipótese é de intervenção federal no Estado (art. 10, VI, da Constituição Federall.

É o Presidente da República que se recusa ao cumprimento da decisão? Autoriza-se-lhe a responsabilização (art. 82, VII, da Constituição Federah.

Verifica-se, portanto, que o constituinte estabeleceu um mecanismo capaz de assegurar a eficácia das decisర̋es judiciais, meras orientaçð̋es ou aconselhamentos. São normas imperarivas do Estado, veiculadas por um dos seus orgãos. 
Os jurisdicionados cumprem-nas porque estão obrigados, pela ordem normativa, a prestar-Ihes obediência. Pena de sofrerem conseqüências (sanção) pelo não cumprimento.

Diferentemente, portanto, do que ocorre com as decisర̃es do Executivo ou de qualquer particular. A estas deliberações (que também resultam do "dizer o direito") o Estado não confere instrumentos que as efetivem.

Isto porque não são definitivas. A definitividade só se opera, como dissemos, no interior do Poder Judiciário. É neste que se forma a 'coisa julgada' (art. 153, § $3^{\circ}$, da Conśtituição Federah). E dele não pode ser excluída nenhuma lesão de direito individual (art. 153, § 4.. , primeira parte, da Constituição Federah.

Nem mesmo a lei - ato normativo imediatamente infraconstitucional e revestido de superior atributividade em relação aos demais - pode ensejar essa exclusão.

Não foi sem razão que o constituinte alojou a garantia de plena acessibilidade ao Judiciário no capítulo dos direitos e garantias individuais.

Ter acesso ao Judiciário significa a possibilidade de os litígios serem solucionados imparcialmente. Por alguém (ou por órgão) que não é parte no feito (in parte).

O julgamento imparcial, por sua vez, visa a preservar o direito individual (aqui entendido, também, o direito dos seres personalizados).

É ojulgamento imparcial, ao lado da lei, como expressão da vontade geral, o fundamento do Estado de direito. Daí Balladore Pallieri ter averbado, como lembra Geraldo Ataliba, que o Estado de direito é aquele em que todos se submetem à lei e à jurisdição.

Jurisdição, portanto, é a competência atribuida a um dos órgáos do Poder (ou a mais de um) para dizer o direito aplicável a uma controvérsia, solucionando-a em caráter definitivo e podendo exigir obediência a essa solução, mediante o emprego de força institucional do Estado.

De tudo resulta a indispensável ligação entre o Estado de direito e a jurisdição. Aquele é fruto de sistema que prestigia a vontade do povo (lei) e os julgamentos imparciais (jurisdição). Difere do Estado chamado absoluto em que a lei e o desate das controvérsias provém da vontade do soberano.

Foram séculos de lutas que levaram os povos a conquistarem o direito à participação nos misteres governamentais. A tal ponto que as constituiçð̋es passaram a patentear, como norma substancial- mente constitucional, a idéia de que o poder emana do povo. Pertence-lhe. Por isso, sendo a fonte geradora do poder (do povo emana), aquele que exerce parcela dele, o faz em nome do povo. Não há possibilidade de exercício do poder que não seja emanação popular.

\section{A Constituicão Brasileira desdobra o preceito} contido no $\$ 1$. , do artigo 1? (todo poder emana do povo e em seu nome é exercido) para revelar a existência de três órgãos exercitadores do poder. De modo que a tripartição do Poder (com a outorga, a cada que deles, de uma função preponderante) é mera conseqüência daquela norma substancialmente constitucional: o Poder é titularizado pelo povo.

Se é assim, há de ser sempre restrita toda interpretação que envolva o exercício daquelas funçôes estatais: a executiva, a legislativa e a judiciária. Porque decorrência de uma norma sem a qual o Estado não pode existir: aquela identificadora do titular do Poder. A norma primeira, reveladora da soberania, como lembra Carlos Ayres Britto.

Expressão máxima do pensamento constituinte é, indubitavelmente, o preceito que indica o senhor do Poder. Antes, o soberano; hoje (fruto de aspiração milenar), o povo.

Frise-se, portanto: um sistema normativo que entrega o Poder ao povo tem, como um de seus suportes, o exercício desse Poder por três órgãos distintos desempenhando, cada um, preponderantemente, uma das funçø̃es.

A nossa Constituição autoriza, no caso do artigo 205, exegese desapegada da sua literalidade para assentar-se em princípios. Daí o havermos discorrido, introdutoriamente, sobre a jurisdição.

\section{A lei e a administração.}

Impende que outra idéia seja fixada. Aquela reveladora de que nada se faz ou se deixa de fazer senão em virtude da lei (art. 153, § 2. , da Constituição Federah.

Assim, no Legislativo, no Judiciário, no Executivo e nas relaçðes particulares, a lei é a fonte impulsionadora de todas as relaçőes que se estabelecem.

Todos agem segundo a lei. A desobediência importa sanção. O Executivo não escapa a essa regra. Seu dever é executar, administrar, dar o disposto na lei.

Para cumprir esse dever, aparelha-se de tal modo que uma parte da atividade é desempenhada diretamente, por meio de órgãos que se ligam uns aos outros pela relação de hierarquia. 
Desconcentra-se a administração. Criam-se centros decisórios. Todos, porém, submetidos a um sistema de vinculação hierárquica. Não se criam pessoas. Criam-se órgãos componentes de um organismo.

De outro lado, descentraliza-se a administração. Já, agora, com vistas a agilizar o aparelho administrativo de tal arte que melhor se cumpra a vontade legal. Aqui, nascem pessoas. Seu criador é a lei. Esta é quem Ihes dá nascimento atribuindo-lhes competências. A lei cria diretamente a entidade lautarquia) ou lhes autoriza a criação. O certo é que não haverá criação de qualquer entidade sem prévia manifestação legislativa.

Determina-se que o ser criado desempenhe certas atividades. Ou seja: dê cumprimento à lei, à vontade geral. Já, agora, não por meio da administração direta (com objetivos também fixados na lei) mas por intermédio de uma forma indireta, descentralizada, de.administrar. É dessa atividade legal que surgem as autarquias, as empresas públicas e as sociedades de economia mista. Não nascem do Executivo. Este Ihes dá vida, atendendo, porém a comando legal. Nem desempenham competência por ele determinada. Desenvolvem misteres preceituados na lei.

Sendo assim, tanto a administração direta quanto os vários entes da indireta exercitam atividades que revelam o interesse geral. Não o do Executivo. Mas o da lei (emanação da vontade geral).

Bem por isso, podem surgir conflitos entre a pessoa política ${ }^{1}$ (União, Estados e Municípios) e as pessoas administrativas ou entre umas e outras (autarquias, empresas públicas e sociedades de economia mista). Conflitos de interesses. De quem? podemos perguntar. Interesses públicos, ou seja, do povo que veiculou seu desejo mediante a expedição de ato normativo.

As entidades descentralizadas constituem emanação da lei e seu dever é desempenhar funçס̃es que aquela Ihe ordenou.

Tais interesses - porque públicos - hão de ser defendidos pelos seres personalizados. Ao buscar preservá-los, estarão atendendo ao sistema legal que lhes deu vida.

Tenha-se presente a advertência clara e precisa de Seabra Fagundes: "administrar é aplicar a lei de ofício".

Assim, na ocorrência de controvérsia entre a União e suas entidades descentralizadas ou entre estas, os litigantes estarão defendendo, imediatamente, interesses seus, mas, mediatamente, interesses determinados pelo legislador.
Repita-se e saliente-se que os seres descentralizados não constituem mero prolongamento da administração centralizada, mas desdobramento da vontade legal.

Evidente que as administraçס̃es centralizada e descentralizada têm, no chefe do Executivo, o comandante supremo. Mas, essa chefia é caracterizada para fins administrativos. De unidade da Administração. No caso das entidades descentralizadas o controle exercido pelo Executivo visa, precipuamente, a assegurar o cumprimento dos fins assinalados pela lei. E a tutela administrativa.

Presidente, Governadores, Prefeitos não são determinadores de condutas, nem fixadores de interesses. Chefiam, para cumprir e fazer cumprir a lei. Respalda essa afirmação o art. 81, III, do texto constitucional.

Como síntese, a idéia matriz: se a administração centralizada e os seres componentes da descentralizada hão de agir segundo a lei, perseguindo interesses por ela fixados, deles nascem direitos, que não são do Executivo, apenas. São do povo que os expressa por meio da lei. Eventuais ofensas a tais direitos hão de ser solucionadas por juízo imparcial.

O art. 205 da Constituição Federal - Aqui, podemos entrar no tema central deste trabalho: o art. 205 da Constituição Federa/ não enseja a inapreciação, pelo Judiciário, das questర̋es entre as pessoas políticas (inclusive o Distrito Federal) e as pessoas administrativas ou destas, entre si.

Em outras palavras: a garantia constitucional da jurisdição (tal como a descrevemos) alcança, também, os litígios entrevistos no art. 205 da Constituição Federal.

Ada Pelegrini Grinover, preocupada com a subtração desses litígios da apreciação do Judiciário, salienta que a lei instituidora do contencioso deverá necessariamente assegurar aos litigantes o due process of law! Ou seja, ressalta aquela jurista, " desde que assegurasse, em primeiro lugar, o juiz natural, imparcial e pré-constituído, e desde que tutelasse outros direitos processuais, como a igualdade, a defesa, o contraditório, a publicidade, o duplo grau de jurisdição" 10 Contencioso Administrativo na Emenda n: 7/1977, Revista da Procuradoria-geral do Estado de São Paulo - P.G.E., n? 10, p. 247 I 279).

Embora, esteja aludindo a autarquias de regime especial, esclarece que a lei instituidora do contencioso deverá, quando menos, prever a revisão judiciária da decisão administrativa.

Kazuo Watanabe, comentando a doutrina existente a propósito do contencioso previsto no 
art. 205, sustentou que o art. 205 não estabelece exceção ou limitação ao princípio do monopólio da jurisdição, pelo Judiciário.

Afirma que é “...perfeitamente possível a configuração de um conflito de interesses, de uma lide, em que de um lado se coloca a posição da autoridade administrativa sustentando um interesse ilegítimo e de outro a posição da emanação, defendendo a prevalência do interesse público". Acrescenta, que a circunstância de deixar a decisão definitiva a uma autoridade administrativa significa deixar sem controle atos ilegítimos "o que contraria o nosso sistema jurídico contitucional, de Estado de Direito, em que o próprio Estado se submete à ordem jurídica" IControle jurisdicional e Mandado de Segurança contra atos judiciais, Editora Revista dos Tribunais, p. 73).

De fato, 0 art. 205 não subtrai o judiciário as questões nela previstas. Até porque, como antes expressamos, todos os entes estatais e paraestatais não constituem emanação do próprio Executivo liá que 0 art. 205 aludindo à União, Estados e Municípios está se ferindo a Administração centralizada. Também assim (no caso do Distrito Federal) mas, sim, da lei.

De toda forma é preciso explicar, interpretando o texto constitucional, qual a exata significação do art. 205, uma vez que dois argumentos poderiam levar à convicção - generalizada na doutrina - de que ali se permite a criação de verdadeiro contencioso administrativo.

São eles: a) a exposição de motivos do anteprojeto da Emenda Constitucional n. ${ }^{\circ} 7 / 1977$ que salientou: "Embora, a nosso ver, fosse desnecessária, parece conveniente, em face da orientação dos tribunais, a consagração em preceito constitucional, de que as questőes surgidas entre União, suas autarquias e empresas públicas sejam decididas, em definitivo, pela autoridade administrativa competente; b) a circunstâncias de o art. 203, que autoriza a criação de contenciosos administrativos federais e estaduais para decisão de questð̋es fiscais, previdenciárias e relativas a acidentes do trabalho prescrever, expressamente, que não têm poder jurisdicional, o que poderia induzir o intérprete, somando a literalidade daquele dispositivo com a intentio legislatoris, a concluir que este tem poder jurisdicional. Assim, se a decisão prevista no art. 205 é destituída da força própria a jurisdição não haveria necessidade de alojá-la em outro dispositivo: haveria de estar presente no artigo 203 que alude a decisð̃es desprovidas de força jurisdicional.

Em primeiro lugar, se a intenção do legislador não coincide com a norma efetivamente produzida, prevalecerá a intelecção desta e não dos desígnios do proponente da norma. A inteligência desta, por sua vez, só pode ser alcançada mediante a interpretação de todo o sistema dela regente. Essa interpretação sistemática - já vimos - prestigia a lei e a jurisdição. Não pode ser prestigiada interpretação que vise a fazer prevalecer o desejo de quem deflagrou 0 processo de elaboração daquela norma.

Por outro lado, o que se deduz de todo o sistema normativo atinente aos chamados contenciosos administrativos, previstos nos artigos 111 e 203, é que o constituinte, nesse particular, conferiu faculdade ao legislador ordinário permitindo-lhe que, ao criar aqueles contenciosos, condicionasse o ingresso em juízo à exaustão da via administrativa. É o que está escrito na segunda parte do parágrafo $4{ }^{\circ}$ do art. 153: " 0 ingresso em juízo poderá ser condicionado a que se exauram previamente as vias administrativas desde que não exigida garantia de instância, nem ultrapassado o prazo de 180 dias para a decisão sobre o pedido"

Já não ocorre o mesmo com a hipótese do art. 205. Necessariamente as pessoas ali mencionadas hão de trilhar a via administrativa antes de ingressar no Judiciário. O constituinte, nesse passo, não conferiu faculdade ao legislador ordinário. Disse que as questões ali previstas serão decididas pela autoridade administrativa, na forma da lei. Mas este dizer significa autorização para o legislador ordinário determinar o modo, o procedimento, o meio conducente à prolação da decisão administrativa. Não o autoriza - diferentemente das hipóteses do 111 e 203 - a facultar ou não, o percurso ${ }^{2}$ da instância administrativa quando se tratar de litigios ocorrentes entre os seres mencionados naquele dispositivo. De modo que, para ingressar no Judiciário (quando a lei ordinária estabelecer a forma de procedimento), as pessoas arroladas no art. 205 haverão de fazer pro$\mathrm{va}$, com a inicial, de que percorreram a instância administrativa. Não é o legislador ordinário quem decidirá esta matéria, pois a decisão do trânsito obrigatório pelo tribunal administrativo já foi decidido pelo constituinte. Daí porque a hipótese do art. 205 foi alojada em dispositivo distinto.

Restaria examinar a ressalva que faz da parte final do art. 205. Ali se permite ao acionista procedimento anulatório da decisão proferida pela autoridade administrativa no julgamento das questð̋es que 0 dispositivo menciona.

Explica-se essa preocupação do constituinte. $\mathrm{O}$ acionista não participa, enquanto tal, do litígio ocorrente entre uma pessoa administrativa (de que faça parte naquela qualidade) e outra entidade da Administração. A decisão poderá importar em vulneração a direitos seus. Se o dispositivo constitucional nada dissesse a propósito dessa matéria poderia o acionista, indubitavelmente, postular no Judiciá- 
rio a anulação daquela decisão por que em detrimento de seus interesses. Seria até absurdo supor que alguém, reconhecidamente prejudicado por decisão administrativa, ficasse impedido de sair em defesa de seu direito. Para tanto, não há necessidade da parte final do artigo comentado. A autorização já se encontra no artigo $153, \S 4{ }^{\circ}$, primeira parte (a lei não poderá excluir da apreciação do Judiciário qualquer lesão de direito individual).

$\mathrm{O}$ que o art. 205 fez, nesse caso, foi garantir procedimento anulatório perante a própria autoridade administrativa. Quer isto dizer que a decisão administrativa poderá ser anulada por outra decisão administrativa mediante provocação do acionista que por ela se viu prejudicado.

Poder-se-ia argumentar com a garantia constitucional do direito de petição e de representação (art. 193, § 30). Ou seja: o acionista já teria o direito de peticionar à Administração independentemente da autorização da parte final do artigo 205.

Ocorre que são coisas distintas. A petição ou a representação não obrigam à Administração a decidir sobre o pedido ou sobre o fato de que teve ciência ${ }^{3}$.

No procedimento anulatório de que se cuida, a Administração fica obrigada a proferir decisão quanto à insurgência do acionista.
Somente esta intepretação é compatível com o sistema constitucional indicado e com a idéia de Estado de direito, que vem consagrada no $\S 1^{\circ}$. do artigo 1. da Constituição Federal.

\section{Notas}

1. A Constituição Federal, no artigo 205, alude à União, Estados e Municípios para categorizá-los como a Administraçăo direta. Tanto que menciona conflitos com suas autarquias, empresas públicas e sociedades de economia mista (Administração indireta).

2. É sabido que a Constituição vigente foi várias vezes emendadas com vistas à solução de casos determinados. Muitas vezes o proponente da Emenda Constituciona/ se esquece de que, produzida, passa a integrar um corpo orgânico-legale, por isso, será interpretada em função da posiçãc que ocupa nesta estrutura. Não se a interpreta desligada de todo o sistema.

3. Já tivemos ocasião de expor: "Na representação se dá notícias do fato abusivo para que os Poderes Públicos providenciem as medidas adequadas. Na petiçăo se solicita, se pede medida que defenda direito. A representação visa a reprimir os abusos de autoridade; a petição visa a prevenir a vulneração a direito (dai por que por ela visa a defender direito)".

De qualquer forma ambos os instrumentos não fornecem aos seus utilizadores meios de compulsão para o seu atendimento. (Elementos de direito Constitucional, Editora Revista dos Tribunais, p. 236). 